Original Research Paper

\title{
Pengembangan Atraksi Agrowisata Taman Bunga sekaligus sebagai Sumber pakan Lebah Trigona untuk Meningkatkan Kapasitas Produksi Madu Trigona di Desa Lingsar Kecamatan Lingsar
}

\author{
Embun Suryani $^{1 *}$, Sri Wahyulina ${ }^{1}$, Sarifudin Serip ${ }^{1}$, Ni Ketut Surasni ${ }^{1}$, Muhamad Ahyar1 ${ }^{1}$ L.M. Furkan ${ }^{1}$ \\ ${ }^{1}$ Fakultas Ekonomi dan Bisnis, Universitas Mataram, Mataram, Indonesia
}

https://doi.org/10.29303/jpmpi.v3i2.1144

Sitasi: Suryani, E., Wahyulina, S., Serip, S., Surasni, N. K., Ahyar, M \& Furkan, L.M. (2021). Pengembangan Atraksi Agrowisata Taman Bunga sekaligus sebagai Sumber pakan Lebah Trigona untuk Meningkatkan Kapasitas Produksi Madu Trigona di Desa Lingsar Kecamatan Lingsar. Jurnal Pengabdian Magister Pendidikan IPA 4(4)

\section{Article history}

Received: 02 Oktober 2021

Revised: 20 Oktober 2021

Accepted: 09 November 2021

*Corresponding Author:

Embun Suryani, Fakultas

Ekonomi dan Bisnis

Universitas Mataram, Mataram,

Indonesia

Email:

embunsuryani@unram.ac.id

\section{Pendahuluan}

Kecamatan Lingsar dengan luas wilayah 96,58 $\mathrm{km}^{2}$ yang memiliki potensi di bidang

\begin{abstract}
Desa Lingsar merupakan salah satu desa di Kabupaten Lombok Barat yang terdampak bencana gempa bumi tahun 2018. Daerah ini berpotensi untuk mengembangkan agrowisata karena 53\% wilayahnya terdiri dari perkebunan tanaman buah-buahan, penghasil bibit tanaman buah-buahan serta penghasil buah-buahan terbesar di Provinsi NTB. Untuk itu, Desa Lingsar memiliki potensi yang besar untuk mengembangkan budidaya lebah madu trigona, karena memiliki sumber pakan lebah yang cukup berlimpah. Budidaya lebah madu trigona dan produk-produk turunannya merupakan salah satu upaya untuk memberdayakan masyarakat yang berbasis ekonomi kreatif, yang diharapkan dapat berkontribusi dalam meningkatkan pendapatan masyarakat. Saat ini, budidaya lebah madu trigona oleh masyarakat Desa Lingsar hanya dalam skala kecil, sehingga belum mampu memberikan dampak yang signifikan untuk meningkatkan kesejahteraan masyarakat desa. Hambatan terbesar yang dihadapi kelompok usaha madu trigona di Desa Lingsar adalah keterbatasan sumber pakan pada saat di luar musim buah. Kondisi ini menyebabkan potensi madu trigona tersebut belum mampu dikelola secara optimal untuk meningkatkan kesejahteraan masyarakat. Untuk itu, kegiatan ini bertujuan untuk mengembangkan kapasitas produksi madu trigona melalui pengembangan sumber-sumber pakan dari tanaman bunga, yang sekaligus dapat dikelola sebagai atraksi agrowisata. Target yang ingin dicapai dari kegiatan ini adalah semakin meningkatnya produktifitas madu trigona yang bisa dihasilkan kelompok madu trigona di Desa Lingsar, sekaligus mengembangkan atraksi baru dari sentra agrowisata di desa tersebut. Untuk mencapai target tersebut, model pendekatan yang digunakan adalah Participatory Rural Appraisal (PRA) yang menekankan keterlibatan masyarakat dalam keseluruhan kegiatan mulai dari perencanaan, pelaksanaan dan evaluasi program. Kegiatan ini terdiri dari tiga kegiatan yaitu penyuluhan, demplot (demonstration plot), dan pendampingan budidaya tanaman bunga sekaligus budidaya madu trigona dan diversifikasi produk turunan. Kelompok sasaran dari kegiatan ini yaitu Kelompok Usaha Madu Trigona Repoq Bangket Desa Lingsar.
\end{abstract}

Keywords: Atraksi Agrowisata, Taman bunga, pakan lebah trigona, madu trigona, Lingsar

pertanian dan perkebunan karena lebih dari $50 \%$ wilayah Kecamatan Lingsar merupakan kawasan pertanian dan perkebunan yang ditanami dengan tanaman buah-buahan seperi tanaman Manggis, 
rambutan dan mangga terdapat hampir diseluruh wilayah. Hal ini didukung oleh karakteristik struktur perekonomian Kecamatan Lingsar masih bercorak agraris yang menunjukkan bahwa masyarakat mengolah dan menggunakan sawah secara optimal sebagai mata pencaharian.

Desa Lingsar merupakan salah satu desa dari 15 (lima belas) desa di Kecamatan Lingsar Kabupaten Lombok Barat. Desa ini memiliki potensi dibidang pertanian, perikanan, perdagangan dan industri rumah tangga. Selain itu desa ini juga merupakan desa yang memiliki potensi alam, lingkungan dan budaya yang sangat penting untuk mendukung dikembangkannya agrowisata. Slogan Back to Nature mendorong terjadinya perubahan preferensi wisatawan global maupun domestik terhadap semakin tingginya permintaan terhadap wisata alam. Preferensi wisatawan berkembang secara dinamis, dimana kecenderungan pemenuhan kebutuhan dalam bentuk menikmati obyek-obyek spesifik seperti udara segar, pemandangan yang indah dan hijau, pengolahan produk secara tradisional, maupun produk-produk pertanian modern dan spesifik menunjukkan peningkatan yang pesat (Pamulardi, 2006). Sentra agrowisata belakangan ini banyak diminati oleh wisatawan asing dan lokal yang setiap tahun jumlahnya terus bertambah. Disamping itu sentra agrowisata merupakan tujuan wisata alternatif yang menyajikan berbagai pengalaman unik, menarik dan dengan harga yang relatif lebih murah dibanding tujuan wisata lainnya.

Selain itu, hampir semua desa di kecamatan Lingsar merupakan kawasan pertanian dan perkebunan yang ditanami dengan tanaman buahbuahan seperti tanaman manggis, rambutan dan mangga terdapat hampir diseluruh wilayah. Kondisi ini menyebabkan wilayah ini memiliki potensi yang besar untuk mengembangkan budidaya lebah madu trigona. Potensi yang besar ini harus didukung oleh pemanfaatan yang optimal, agar dapat memberikan manfaat terhadap peningkatan kesejahteraan dan pendapatan masyarakat. Lebah madu merupakan kelompok serangga yang berperan sebagai agen polinator tanaman berbunga, sehingga dapat meningkatkan produksi tanaman tersebut (Corlett, 2011). Sedangkan, lebah madu trigona (Trigona $s p$.) merupakan jenis lebah yang tidak men yengat dan merupakan lebah tertua yang pernah diketahui (Sihombing, 2005).
Saat ini, lebah madu trigona dibudidaya oleh masyarakat Desa Lingsar hanya dalam skala kecil, sehingga belum bisa memberikan manfaat ekonomis bagi masyarakat. Hal ini disebabkan karena kurangnya pengetahuan masyarakat Desa Lingsar untuk melakukan budidaya sumber pakan selain tanaman buah bagi lebah trigona. Implikasinya adalah potensi yang besar tersebut belum mampu dikelola secara optimal untuk meningkatkan kesejahteraan masyarakat Desa Saribaye.

Untuk itu, melalui kegiatan ini akan diidentifikasi dan dikembangkan budidaya berbagai jenis tanaman bunga sebagai sumber pakan bagi lebah trigona. Mengingat sebagian besar masyarakat Desa Lingsar tidak memiliki lahan yang luas untuk menanam buah-buahan, maka akan diinisiasi terbentuknya "Kampung Madu Trigona" sebagai bentuk pendekatan holistik dan berkelanjutan berbasis hasil-hasil riset multidisiplin untuk mendukung Desa Lingsar sebagai salah satu destinasi agroekowisata di Pulau Lombok. Kampung ini akan dikembangkan di salah satu lahan milik anggota kelompok madu trigona Repoq Bangket, dimana di lokasi tersebut semua anggota kelompok dapat memelihara lebah trigona mereka. Kampung ini akan menjadi sentra budidaya lebah trigona yang dijadikan sebagai sentra agrowisata yang menyajikan berbagai jenis atraksi agrowisata, selain madu trigona, seperti taman bunga yang sekaligus sebagai sumber pakan lebah trigona, wisata memanen madu trigona, menikmati berbagai minuman berbahan madu trigona, dan lain sebagainya.

Adapun tujuan dari kegiatan ini adalah untuk mengembangkan sumber pakan lebah trigona berupa berbagai jenis tanaman bunga dengan tujuan meningkatkan kapasitas produksi usaha madu trigona, selain itu mengembangkan berbagai atraksi agrowisata berbasis potensi local Desa Lingsar. Target yang ingin dicapai dari kegiatan ini adalah semakin meningkatnya kapasitas produksi kelompok madu trigona Repoq Bangket, yang dilaksanakan dengan bermitra dengan Kepala Desa Lingsar dan didukung kelompok sasaran yaitu Kelompok Usaha Madu Repoq bangket Desa Lingsar.

\section{Permasalahan Mitra}


Berdasarkan survey awal dan diskusi dengan Mitra dan tiga kelompok sasaran maka permasalahan prioritas yang akan ditangani terbagi menjadi 5 aspek, yaitu 1) aspek produksi; 2) aspek pemasaram; 3) manajemen (keuangan-permodalan); dan 4) ekonomi.

Aspek produksi: 1) kelompok sasaran masih memiliki kemampuan yang terbatas untuk melakukan budidaya madu trigona dengan baik karena keterbatasan kemampuan dan pengetahuan untuk mengembangkan sumber pakan lebah trigona; dan 2) kelompok sasaran memiliki keterbatasan ketrampilan untuk memisahkan koloni, agar dapat memperbanyak koloni lebah.

Aspek pemasaran: berdasarkan aspek ini ditunjukkan oleh rendahnya kemampuan kelompok sasaran untuk menerapkan berbagai sistem pemasaran terutama yang berbasis cyber marketing. Dengan metode pemasaran ini diharapkan akan memperluas konsumen sasaran.

Aspek manajemen (keuangan-permodalan): 1) kelompok sasaran masih sangat lemah dalam hal permodalan sehingga belum mampu mengakses teknologi tepat guna untuk meningkatkan produktivitas dan kualitas madu; dan 2) kelompok sasaran juga memiliki kemampuan terbatas mengelola keuangan usahanya tersebut.

Aspek ekonomi: Desa Lingsar memiliki tingkat pengangguran usia produktif yang cukup tinggi yang disebabkan karena keterbatasan kualitas sumber daya manusianya. Selanjutnya kondisi ini menyebabkan rendahnya tingkat pendapatan dan daya beli masyarakat.

\section{Solusi dan Target Luaran}

Pariwisata di Pulau Lombok mengalami hambatan yang terus menerus, baru mulai bangkit karena adanya bencana gempa bumi yang berkalikali selama bulan agustus 2018, sektor pariwisata kembali mendapatkan hambatan super besar berupa pandemik covid19 sejak akhir tahun 2019. Kejadian ini memperparah kondisi perekonomian di Pulau Lombok, terutama dilihat dari sektor pariwisata. Untuk itu, pemerintah daerah harus segera berupaya maksimal untuk membangkitkan kembali potensi ekonomi yang dimiliki setiap daerah, terutama setelah terjadi pandemik covid19 ini. Hal ini bisa dilakukan dengan meningkatkan keberdayaan masyarakat desa sehingga pada akhirnya akan terbentuk Desa Mandiri.

Kelompok sasaran yang akan dituju pada kegiatan ini memiliki peran penting dalam pengembangan ekonomi kreatif di desa Lingsa. Berdasarkan permasalahan prioritas, maka solusi yang akan dilakukan yaitu mengembangkan berbagai sumber pakan yaitu berupa tanaman bunga yang sekaligus dapat dibentuk agar menjadi taman bunga yang indah yang dapat menjadi atraksi agrowisata. Budidaya lebah madu trigona dan pengolahan produk turunannya, serta pengembangan agrowisata merupakan bentuk pengembangan ekonomi kreatif yang dilakukan secara berkelanjutan melalui aplikasi pola pelatihan dan pembelajaran, demonstration plot (demplot), dan pendampingan. Cakupan dan sasarannya nampak seperti pada Tabel 1 berikut:

Tabel 1. Permasalahan dan Rencana Kerja

\begin{tabular}{|c|c|c|}
\hline No. & Bidang dan Permasalahan & Solusi yang ditawarkan/ Rencana Kerja \\
\hline 1 & $\begin{array}{l}\text { Produksi } \\
\text { - Kelompok sasaran masih memiliki } \\
\text { kemampuan yang terbatas untuk meningkatkan } \\
\text { kapasitas produksi madu trigona yang } \\
\text { disebabkan oleh: 1) keterbatasan kemampuan } \\
\text { dalam melakukan budidaya berbagai sumber } \\
\text { pakan lebah trigona dengan baik, dan 2) } \\
\text { memiliki keterbatasan untuk memecah koloni } \\
\text { agar dapat meningkatkan jumlah koloni lebah } \\
\text { yang produktif. Selain itu jua, kelompok } \\
\text { sasaran memiliki keterbatasan untuk mengolah } \\
\text { berbagai minuman yang berbahan madu. }\end{array}$ & $\begin{array}{l}\text { - Memberikan pengetahuan dan pelatihan kepada } \\
\text { kelompok sasaran guna meningkatkan kemampuan } \\
\text { dan ketrampilan kelompok sasaran untuk melakukan } \\
\text { budidaya lebah madu trigona yang modern dengan } \\
\text { manajemen usaha yang professional, serta budidaya } \\
\text { berbagai jenis tanaman sebagai sumber pakan lebah } \\
\text { trigona. } \\
\text { - Mendesain kemasan yang menarik dan hygienis untuk } \\
\text { menghasilkan produk Madu Trigona yang memiliki } \\
\text { nilai jual yang tinggi. }\end{array}$ \\
\hline
\end{tabular}




\section{Pemasaran}

Rendahnya kemampuan kelompok sasaran untuk menerapkan berbagai sistem pemasaran terutama yang berbasis cyber marketing. Akibatnya kelompok sasaran tidak akan mampu memperluas konsumen sasaran untuk destinasi agrowisatanya, dan produk-produk yang dihasilka

\section{Manajemen (keuangan-permodalan)}

- Bagaimana mendukung pelaksanaan dan kelancaran usaha mandiri masyarakat desa Lingsar dari sisi penyiapan permodalan dan pengelolaan keuangan usaha.

- Bagaimana meningkatkan kapasitas BUMDes dalam mengelola kegiatan-kegiatan ekonomis masyarakat melalui aplikasi sistem informasi akuntansi
Merancang metode pemasaran yang berbasis online salah satunya dengan memanfaatkan sosial media dan mendesign vlog bagi destinasi agrowisata Desa Lingsar. Dengan metode pemasaran ini diharapkan produkproduk yang dihasilkan oleh kelompok sasaran dapat disosialisasikan secara lebih efektif dengan berbasis inovasi dan IT.

- Mendampingi kelompok sasaran dan masyarakat dalam menjalankan usaha mandirinya dengan manajemen yang professional

- Melatih, membina, dan mendampingi penguruspengurus BUMDes dalam mengelola BUMDes sebagai badan usaha milik desa yang mewadahi kegiatan-kegiatan ekonomis masyarakat.

\section{Ekonomi}

- Mengurangi tingkat pengangguran

- Meningkatkan pendapatan dan daya beli masyarakat agar dapat meningkatkan kesejahteraan mereka

- Melibatkan seluruh lapisan masyarakat desa Lingsar dalam mengembangkan berbagai bentuk ekonomi kreatif salah satunya melalui budidaya lebah madu trigona secara berkelanjutan

\section{Target dan Luaran}

Target dan luaran serta indikator capaian yang diharapkan dari Pengabdian kepada Masyarakat (PKM) ini disajikan pada Tabel 2 berikut ini.

\section{Tabel 2. Rencana Target dan Luaran}

\begin{tabular}{|c|c|c|}
\hline No & Jenis Luaran & Indikator Capaian \\
\hline \multicolumn{3}{|c|}{ Kegiatan pada aspek produksi } \\
\hline 1 & $\begin{array}{l}\text { - Pelatihan keterampilan budidaya tanaman bunga } \\
\text { sebagai sumber pakan lebah trigona, serta } \\
\text { pengembangan berbagai atraksi agrowisata. } \\
\text { - Penyuluhan tentang kebersihan (higienitas) } \\
\text { produk }\end{array}$ & $\begin{array}{l}\text { - Meningkatnya kapasitas produksi madu trigona yang } \\
\text { dihasilkan } \\
\text { - Meningkatnya nilai ekonomis dari madu trigona yang } \\
\text { dihasilkan dan terbentuknya produk khas desa Lingsar } \\
\text { yang berkualitas dilihat dari aspek rasa, kebersihan } \\
\text { dan kemasan. } \\
\text { - Meningkatnya atraksi agrowisata yang dimiliki oleh } \\
\text { sentra agrowisata Kampung Madu desa Lingsar. } \\
\text { Pendapatan kelompok sasaran program menjadi } \\
\text { meningkat }\end{array}$ \\
\hline \multicolumn{3}{|c|}{ Kegiatan pada aspek manajemen usaha } \\
\hline 1 & Pelatihan tentang pengelolaan keuangan & $\begin{array}{l}\text { Kelompok sasaran dapat melakukan pencatatan dan } \\
\text { pengelolaan pendapatan maupun pengeluaran dari usaha } \\
\text { yang dilakukan }\end{array}$ \\
\hline 2 & Pelatihan manajemen pemasaran & $\begin{array}{l}\begin{array}{l}\text { Kelompok sasaran mampu meningkatkan volume } \\
\text { penjualannya }\end{array} \\
\end{array}$ \\
\hline
\end{tabular}




\section{Metode}

Berdasarkan solusi atas permasalahan prioritas desa dan untuk mewujudkan ekonomi kreatif melalui pengembangan destinasi agrowisata dengan madu trigona sebagai daya tarik utama desa Lingsar, maka kegiatan ini akan dilakukan melalui pendekatan Participatory Rural Appraisal (PRA) Community development. Kedua pendekatan ini menekankan keterlibatan masyarakat secara langsung sebagai subyek dan obyek dalam pelaksanaan keseluruhan kegiatan mulai dari perencanaan, pelaksanaan dan evaluasi program kegiatan.

Sedangkan metode yang digunakan untuk melaksanakan kegiatan ini adalah Kaji Tindak Partisipatif melalui pelatihan, pembelajaran, Demonstration plot (Demplot), dan pendampingan secara berkelanjutan dan berkolaborasi dengan kelompok sasaran.

\section{Teknis Pelaksanaan Kegiatan}

Teknis pelaksanaan kegiatan PKM di desa Lingsar adalah sebagai berikut:

\section{Persiapan.}

Pada tahap persiapan ini dilakukan untuk menginventarisasi adanya perubahan kondisi masyarakat terkait pengetahuan, keterlibatan, dan ketrampilan yang dimiliki masyarakat dalam mengembangkan ekonomi kreatif di desa Lingsar. Selanjutnya, juga dilakukan inventarisasi kapabilitas dari kelompok sasaran binaan yang akan menjadi ujung tombak pengembangan usaha budidaya lebah madu trigona dan sentra agrowisata sehingga desain kegiatan yang telah dilakukan dapat memberikan solusi bagi permasalahan mitra. Selain itu di tahap awal ini juga akan dilakukan sosialisasi program secara lebih luas.

\section{Pelaksanaan kegiatan.}

Pelaksanaan kegiatan meliputi kegiatan penguatan kelompok melalui kegiatan pelatihan/workshop, demplot dan pendampingan pengembangan usaha usaha budidaya lebah madu trigona. Workshop dilakukan untuk memberikan pemahaman yang lengkap kepada para peserta tentang cara budidaya berbagai jenis tanaman bunga sebagai sumber pakan lebah trigoan, cara memecah koloni, cara pengedalian hama dan penyakit, cara pemanenan lebah secara modern dan manajemen pemasarannya.

\section{Evaluasi dan monitoring kegiatan.}

Evaluasi dan monitoring kegiatan dilakukan secara periodik dengan melibatkan anggota pelaksana. Evaluasi ini dilaksanakan untuk mengetahui derajat keberhasilan kegiatan berdasarkan target yang telah ditetapkan. Hasil evaluasi kegiatan akan dijadikan dasar untuk membuat kebijakan dan program pengembangan pada tahap berikutnya.

Tabel 3 berikut menggambarkan secara terperinci uraian kegiatan Program Pengabdian pada Masyarakat Kemitraan di Desa Lingsar.

Tabel 3. Uraian Kegiatan Program Pengabdian pada Masyarakat Kemitraan di Desa Lingsar

\begin{tabular}{|c|c|c|c|}
\hline No. & Uraian & Metode & $\begin{array}{c}\text { Peran Pemerintah } \\
\text { Desa }\end{array}$ \\
\hline 1 & $\begin{array}{l}\text { Produksi } \\
\text { - Meningkatkan kapasitas masyarakat desa } \\
\text { umumnya dan kelompok sasaran khususnya } \\
\text { dengan mengembangkan berbagai kegiatan } \\
\text { ekonomi kreatif. } \\
\text { - Melatih, melakukan demplot dan pendampingan } \\
\text { pengembangan sumber pakan lebah trigona dan } \\
\text { pemecahan koloni lebah trigona } \\
\text { - Melatih dan membina ngembangan atraksi sentra } \\
\text { agrowisata dengan madu trigona sebagai produk } \\
\text { utama. }\end{array}$ & $\begin{array}{l}\text { - Focus group discussion } \\
\text { (FGD) dengan seluruh } \\
\text { kelompok masyarakat } \\
\text { dan aparat desa } \\
\text { - Pelatihan dan } \\
\text { pembelajaran } \\
\text { menggunakan } \\
\text { pendekatan andragogis } \\
\text { (pembelajaran orang } \\
\text { dewasa) melalui demplot }\end{array}$ & $\begin{array}{l}\text { - Dukungan tempat dan } \\
\text { sarana untuk } \\
\text { melakukan penyuluhan } \\
\text { dan FGD } \\
\text { - Menggerakkan untuk } \\
\text { ikut berpartisipasi dan } \\
\text { menyediakan sarana } \\
\text { untuk melakukan } \\
\text { demplot }\end{array}$ \\
\hline
\end{tabular}




\begin{tabular}{|c|c|c|c|}
\hline 2. & $\begin{array}{l}\text { Pemasaran } \\
\text { - Merancang dan mendesign vlog bagi produk- } \\
\text { produk ekonomi kreatif dari masyarakat desa } \\
\text { Lingsar } \\
\text { - Merancang dan mendesign brand produk madu } \\
\text { trigona dan sentra agrowisata yang unik dan } \\
\text { berbasis kearifan lokal }\end{array}$ & $\begin{array}{l}\text { - Pelatihan dan workshop } \\
\text { pembuatan website dan } \\
\text { mendesign brand }\end{array}$ & $\begin{array}{l}\text { - Dukungan tempat dan } \\
\text { sarana untuk melakukan } \\
\text { penyuluhan dan FGD }\end{array}$ \\
\hline 3. & $\begin{array}{l}\text { Manajemen (keuangan-permodalan) } \\
\text { - Mendampingi dan melakukan demplot cara } \\
\text { menjalankan usaha dengan manajemen yang } \\
\text { professional } \\
\text { - Membina dan mendampingi pengelolaan } \\
\text { BUMDes secara professional } \\
\text { - Membina dan mendampingi dalam pengelolaan } \\
\text { modal kerja }\end{array}$ & $\begin{array}{l}\text { Demplot dan } \\
\text { pendampingan }\end{array}$ & $\begin{array}{l}\text { - Memfasilitasi kemitraan } \\
\text { usaha masyarakat } \\
\text { khususnya dengan } \\
\text { BUMDes dan LKM } \\
\text { - Memfasilitasi kemitraan } \\
\text { BUMDes khususnya } \\
\text { dengan investor dan } \\
\text { perbankan }\end{array}$ \\
\hline 5. & $\begin{array}{l}\text { Ekonomi } \\
\text { - Seluruh elemen secara kontinyu } \\
\text { mengembangkan produk-produk ekonomi } \\
\text { kreatif yang menunjang pengembangan } \\
\text { agrowisata di Desa Saribaye }\end{array}$ & $\begin{array}{l}\text { - Demplot dan } \\
\text { pendampingan }\end{array}$ & $\begin{array}{l}\text { - Menyiapkan tempat bagi } \\
\text { masyarakat untuk } \\
\text { memulai usahanya } \\
\text { (tempat jualan di } \\
\text { destinasi wisata) }\end{array}$ \\
\hline
\end{tabular}

\section{Hasil dan Pembahasan}

\section{Budidaya Lebah Trigona}

Pada pelaksanaan kegiatan ini dibentuk kelompok usaha madu trigona yang baru, untuk meningkatkan produksi madu trigona Desa Saribaye. Kelompok ini sudah memiliki 75 unit koloni lebah trigona, namun belum memiliki rumah untuk kotak koloni lebah trigona. Untuk itu diberikan bantuan dan pendampingan pembuatan rumah koloni lebah trigona sebanyak 2 unit. Selain itu utnuk meningkatkan produktifitas juga diberikan pendampingan penambahan dan pemecahan koloni lebah madu trigona, terlihat seperti dalam Gambar 1. berikut proses pembuatan kotak koloni lebah trigona.

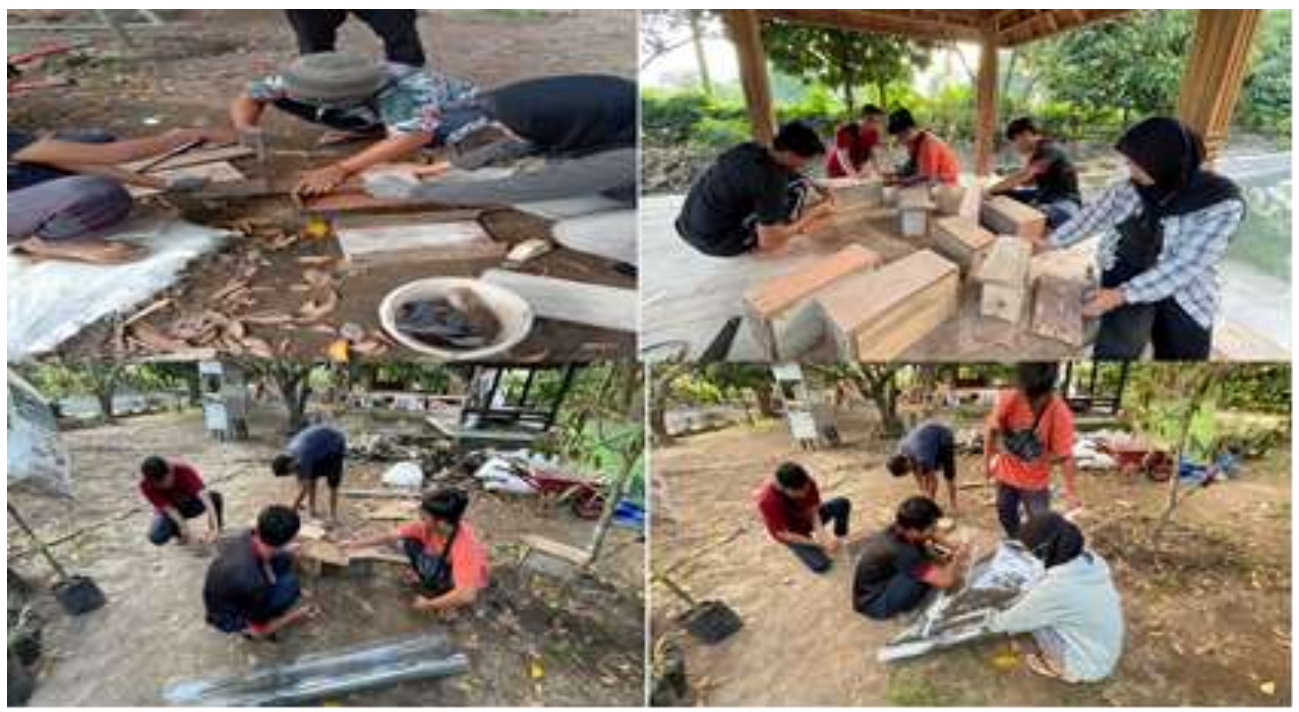

Gambar 1. Proses pembuatan kotak koloni lebah trigona 
Selanjutnya dilakukan juga pemecahan koloni lebah trigona untuk meningkatkan produktifitas madu trigona yang dihasilkan oleh kelompok usaha madu trigona di Desa Saribaye. Gambar 2 berikut ini memperlihatkan proses pemecahan koloni lebah trigona ke dalam kotak-kotak koloni yang telah dibuat seperti pada Gambar 1 di atas.
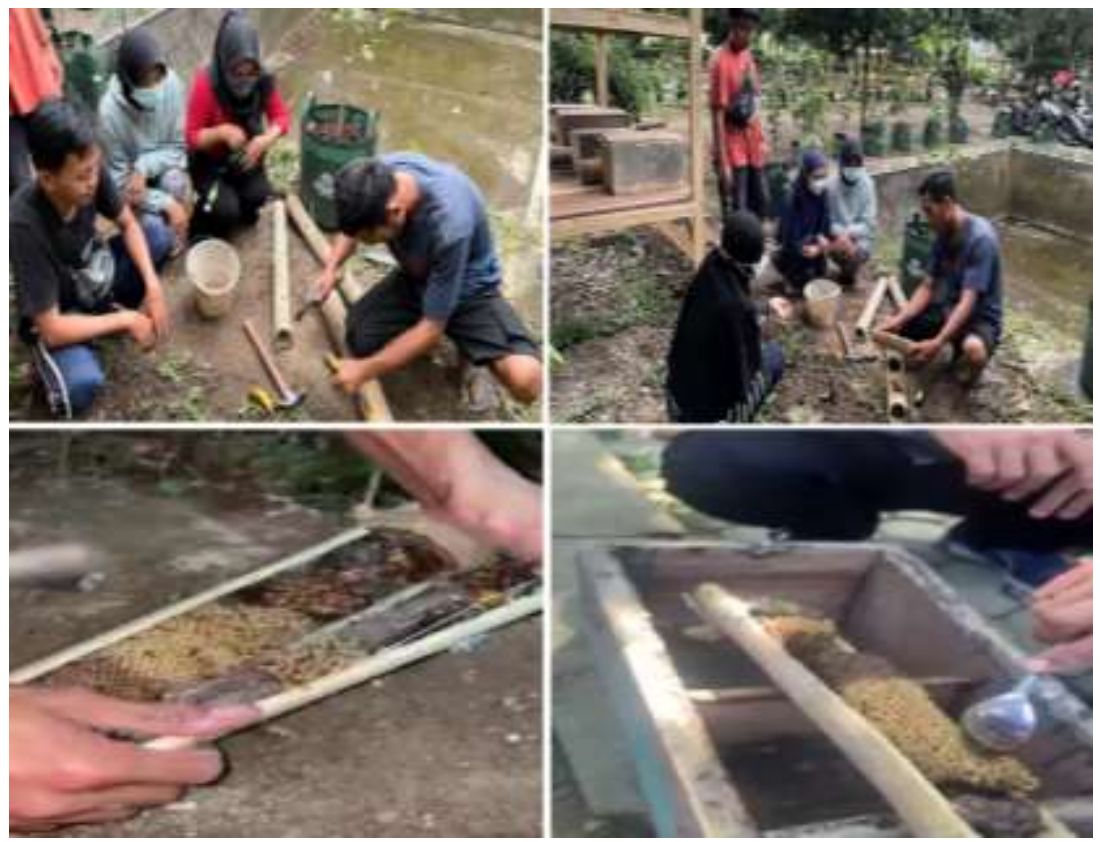

Gambar 2. Proses pemecahan koloni lebah trigona

Budidaya madu trigona membutuhkan perhatian yang ketelatenan peternah untuk memelihara dan menjaga koloni lebah trigona dari predator seperti semut, dan serangga pemangsa lainnya. Masuknya predator ke kotak koloni lebah trigona akan menyebabkan koloni lebah trigona tersebut kabur dari sarangnya. Untuk itu, peternah harus rutin membersihkan lingkungan tempat tinggal lebah trigona. Nampak pada Gambar 3 kegiatan pembersihan lingkungan tempat tinggal koloni lebah trigona
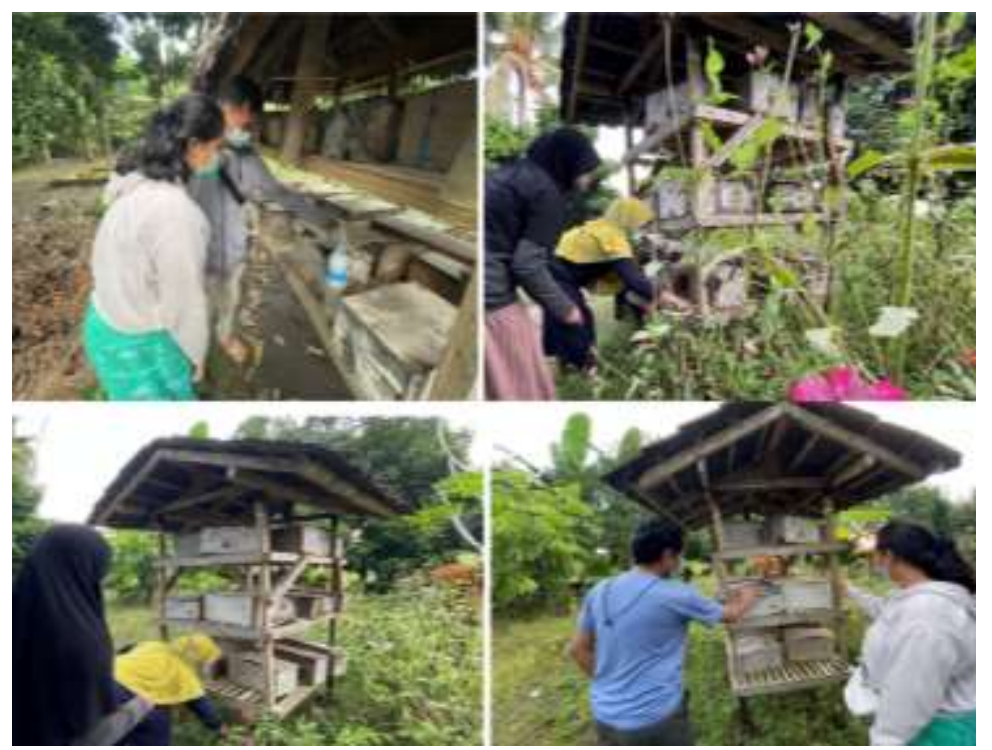

Gambar 3. Kegiatan pembersihan lingkungan tempat tinggal koloni lebah trigona 
Pengembangan Atraksi Budidaya Holtikultura yang mendukung Pengembangan Budidaya Lebah Trigona.

Budidaya madu trigona juga memiliki potensi yang sangat besar untuk dijadikan sebagai salah satu atraksi wisata di Desa Saribaye. Budidaya lebah trigona juga bisa menciptakan berbagai atraksi agrowisata lain, seperti agrowisata buah-buahan dan agrowisata berbagai tanaman holtikultura, seperti jagung, mentimun, tomat, cabe, dan lain sebagainya. Berbagai atraksi agrowisata tersebut mendukung pengembangan sumber pakan bagi lebah trigona.

Pada kegiatan ini dilakukan dibentuk lokasi yang dapat dijadikan atraksi wisata yang terkait dengan budidaya lebah trigona dan budidaya sumber pakannya, Nampak seperti gambar 4 berikut.
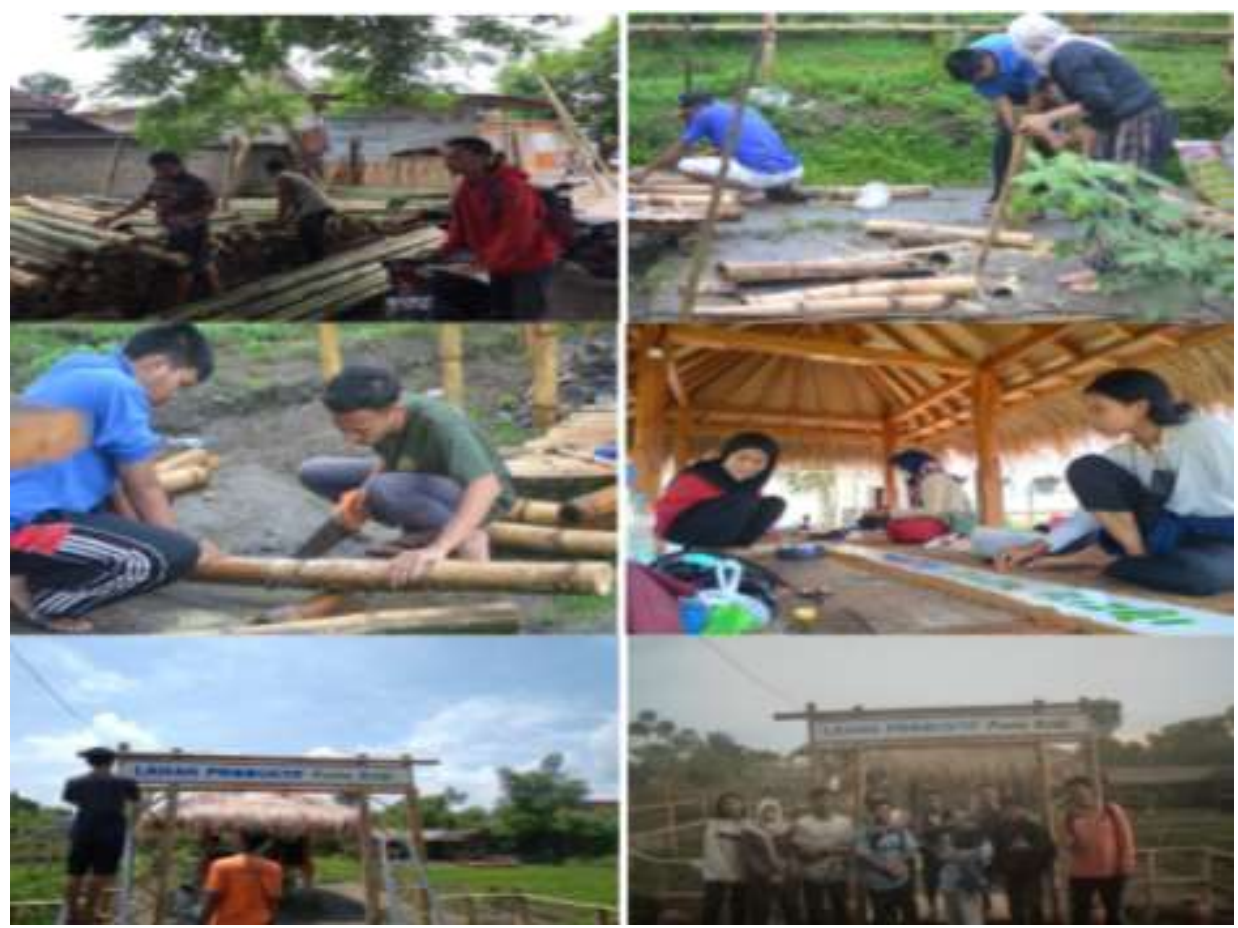

Gambar 4. Kegiatan pengembangan lokasi budidaya lebah trigona dan sumber pakan

Di lokasi tersebut dilakukan budidaya tanaman tumpang sari sebagai sumber pakan madu trigona, yaitu jagung, cabe, mentimun, tomat, kol, dan lainnya. Selanjutnya, hasil dari tanaman tumpang sari ini bisa dijual secara langsung kepada pembeli, dimana pembeli memetik sendiri sayuran yang mereka ingin. Kegiatan ini dapat menjadi hiburan tersendiri bagi masyarakat, terutama masyarakat yang berasal dari kota. Berikut merupakan proses penyiapan lahan untuk menanam jagung manis dan cabe. 


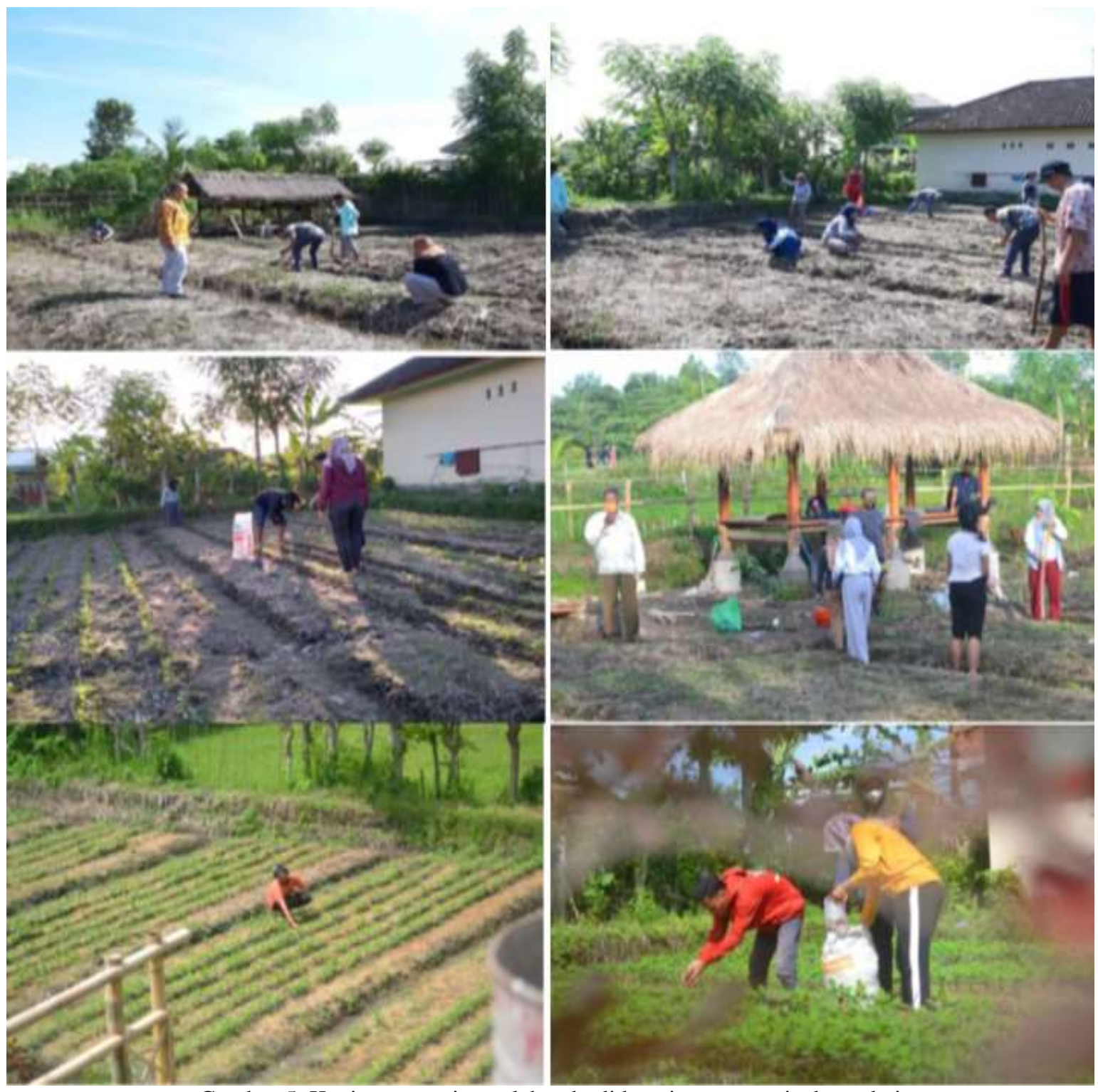

Gambar 5. Kegiatan penyiapan lahan budidaya jagung manis dan cabai

\section{Pengembangan Budidaya Tabulampot dan Tanaman Bunga}

Dilakukan upaya untuk terus menyediakan sumber pakan bagi lebah trigona dengan melakukan budidaya berbagai jenis tanaman bunga dan berbagai jenis tanaman buah. Budidaya tanaman bunga juga menjadi sangat krusial untuk kelangsungan sumber pakan bagi lebah trigona, oleh karena itu dilakukan pengembangan tanaman bunga-bungaan yang menjadi sumber pakan sekaligus memperindah lingkungan dan lokasi budidaya lebah trigona. Tanaman bunga ini juga dapat dijadikan spot photo oleh pengunjung. Budidaya tanaman bunga yang dilakukan oleh kelompok usaha madu trigona dan kelompok petani milenial, serta pembuatan taman bunga nampak pada Gambar 6 berikut. 


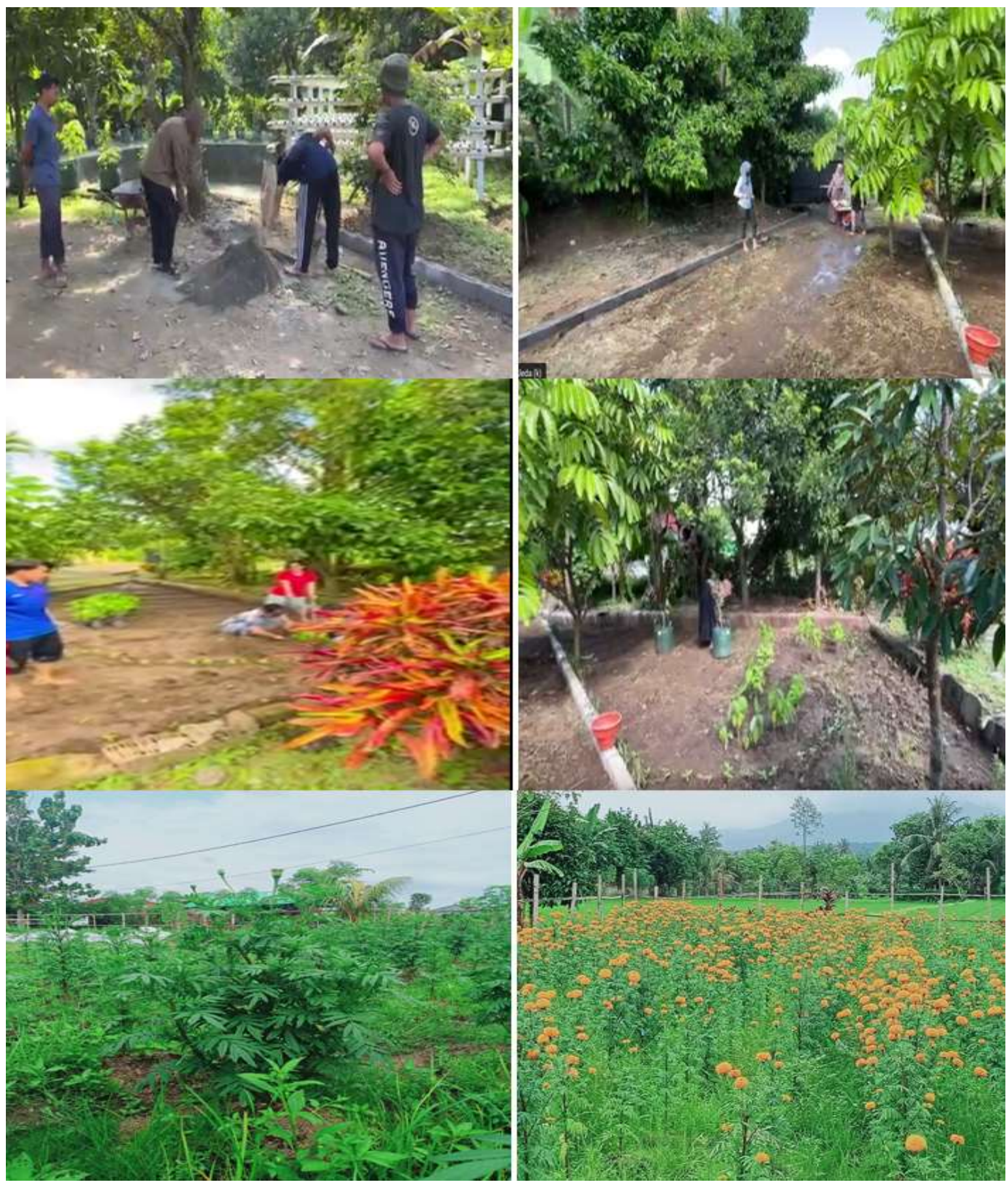

Gambar 6. Budidaya tanaman bunga dan pembuatan taman

Lebih dari itu, tanaman bunga juga memiliki nilai jual yang cukup tinggi, yaitu bunga gumitir, dimana bunga ini digunakan oleh umat hindu, yang banyak terdapat di Lombok, untuk sembayangan. Oleh karena itu, budidaya berbagai jenis tanaman bunga merupakan kegiatan yang potensial untuk meningkatkan sumber pendapatan masyarakat desa Saribaye.
Salah satu potensi terbesar yang dimiliki oleh Desa Saribaye karena terletak di dataran tinggi yang sangat sesuai untuk budidaya tanaman buahbuahan. Selain itu, tanaman buah-buahan juga tetap menjadi pilihan yang tepat sebagai sumber pakan lebah trigona, disamping buah-buahan memiliki nilai jual yang cukup tinggi. Mengingat sebagain besar penduduk desa Saribaye tidak memiliki lahan 
yang luas, maka tanaman buah ditanam dalam pot, atau dikenal dengan Tabulampot.

Dimana, seperti tahun pertama dilakukan pengembangan budidaya tabulampot (tanaman buah dalam pot), tahun ini juga dilakukan penambahan jumlah tabulampot yang dimiliki kelompok masyarakat yang menjadi mitra. Tanaman buah-buahan yang layak untuk dijadikan tabulampot adalah tanaman jeruk, kelengkeng,

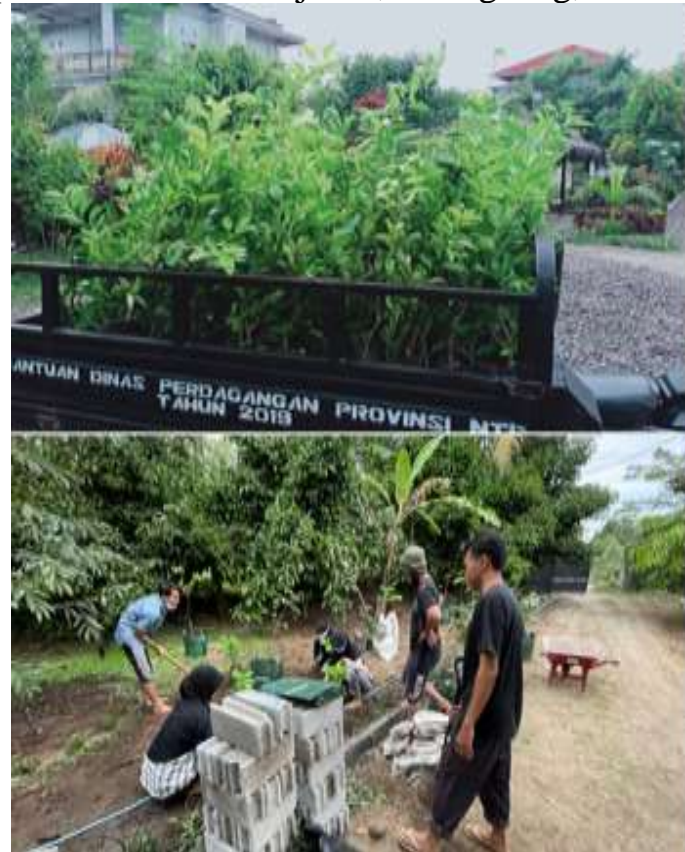

Gambar 7. Budidaya tanaman buah dalam pot (Tabulampot)
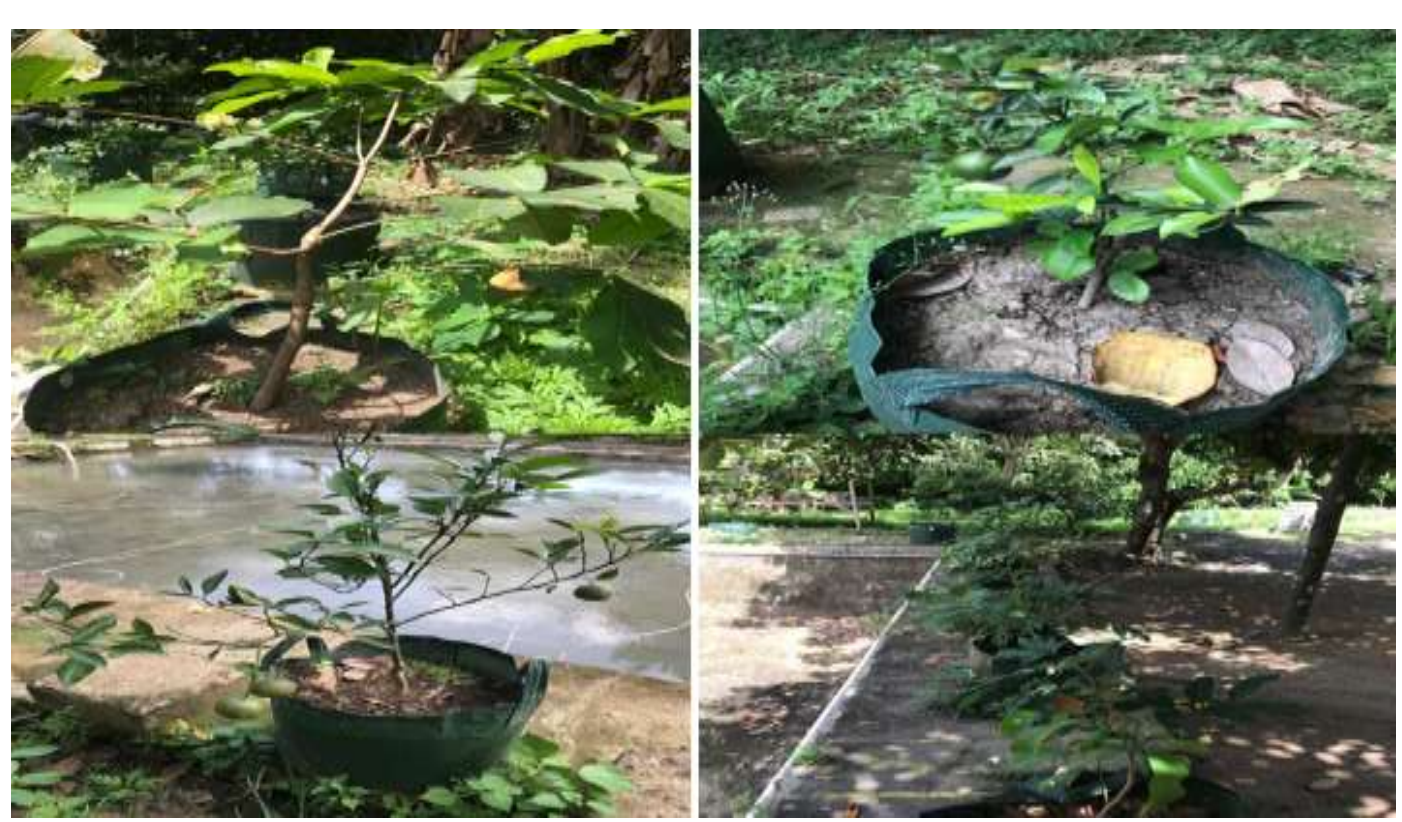

Gambar 8. Tabulampot

jambu Kristal dan jambu air. Berbagai tabulampot ini memiliki prospek yang sangat bagus untuk dikembangkan, selain untuk sumber pakan lebah trigona, tabulampot juga bisa dijual dengan nilai yang cukup mahal, kisaran harga lebih dari 300 ribu rupiah per unit. Gambar 7 dan 8 berikut merupakan kegiatan budidaya tabulampot berupa pohon jeruk, kelengkeng, jambu air, dan jambu kristal.

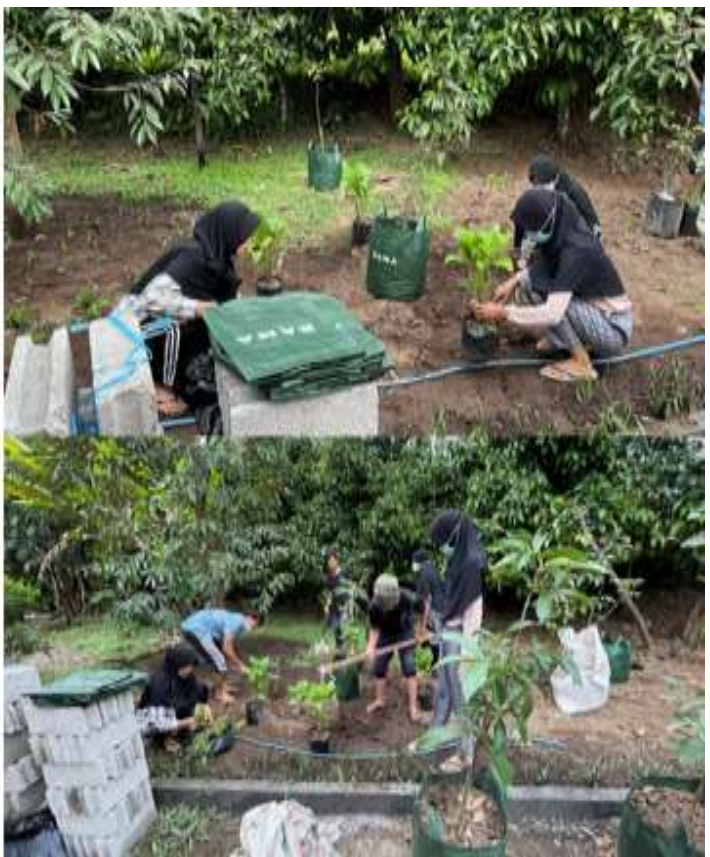


Pengolahan Lilin Aromateraphy Berbasis Bees wax Lebah Trigona

Lilin aromaterapi adalah alternatif aplikasi secara inhalasi (penghirupan), yaitu penghirupan uap aroma yang dihasilkan. Lilin aromaterapi akan menghasilkan aroma yang memberikan efek terapi bila dibakar. Lilin basanya menggunakan bahan paraffin sedangkan lilin yang diolah pada kegiatan ini adalah dengan memanfaatkan limbah pemerasan lebah trigona (beeswax) yang dibudidaya. Sebelumnya, limbah pemerasan ini tidak dimanfaatkan, untuk itu kegiatan ini memberikan
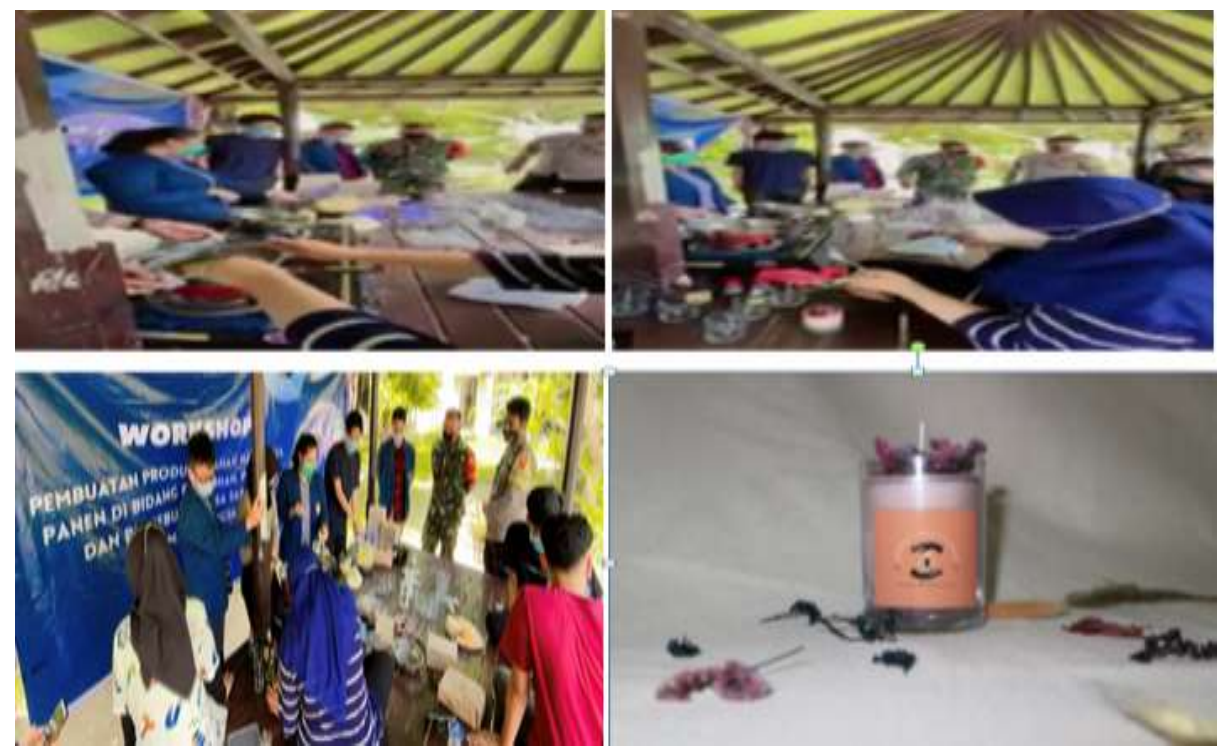

Gambar 9. Kegiatan pengolahan lilin aromateraphy

\section{Kesimpulan}

Secara keseluruhan kegiatan pengembangan budidaya madu trigona melalui pelatihan masyarakat berjalan baik dan lancar. Dampak pelatihan memberikan bekal keterampilan melakukan budidaya madu trigona, meningkatkan kapasitas produksi, proses pemanenan, sampai tahap pengemasan, sehingga produk madu trigona yang dihasilkan memiliki nilai jual yang tinggi. Berbagai materi yang telah diberikan, termasuk manajemen usaha, diharapkan akan membantu memudahkan proses produksi, dan diharapkan dapat berkelanjutan sebagai usaha masyarakat desa. Dengan dikuasainya sejumlah ketrampilan oleh peserta pelatihan akan berdampak juga pada pertumbuhan industri kecil di desa guna peningkatan taraf ekonomi penduduk desa. solusi pemanfaatan limbah hasil ternak lebah trigona menjadi lilin aromaterapi. Keunggulan bees wax yaitu berasal dari lebah, selain menghasilkan aroma yang manis saat dibakar, lili jenis ini memiliki waktu nyala lebih lama dibandingkan paraffin wax atau paraffin coax. Produksi lilin aromaterapi di Desa Saribaye memiliki potensi untuk adanya keberlanjutan hal ini dikarenakan produksi beeswax sebagai bahan baku utama lilin aromaterapi dirasa cukup tinggi. Gambar 9 berikut kegiatan pengolahan lilin aromateraphy. 
Sihombing, D. T. H. 2005. Ilmu Ternak Lebah Madu. Gadjah Mada University Press, Yogyakarta.

Yuni, R., Pebri Hastuti, Roni Afriadi, Putri Sari Silaban (2018). Pengembangan Usaha Ternak Lebah Madu Hutan Nagari Sungai Buluh Nagari Sungai Buluh Timur Kecamatan Batang Anai Kabupaten Padang Pariaman. Jurnal Pengabdian Kepada Masyarakat, Vol. 24(4).

Zulkarnaen, Reza M. (2016). Pengembangan Potensi Ekonomi Desa Melalui Badan Usaha Milik Desa (Bumdes) Pondok Salam Kabupaten Purwakarta. Jurnal Aplikasi Ipteks untuk Masyarakat, Vol. 5(1): 1-4. 